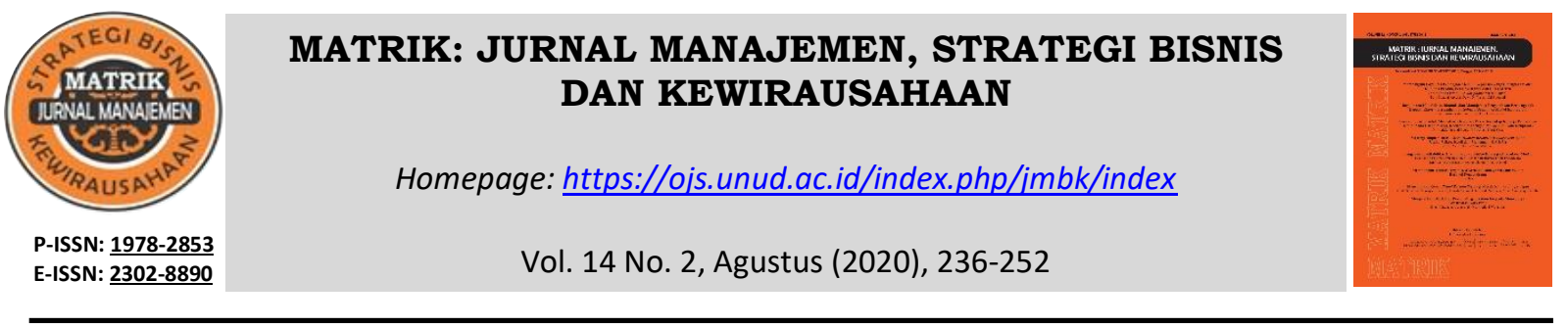

\title{
Analisis Konsumsi Layanan SPA Di Era Baru, Perspektif Theory of Planned Behavior (TPB)
}

\section{Putu Saroyini Piartrini}

Fakultas Ekonomi Dan Bisnis Universitas Udayana

email: royetrini@unud.ac.id

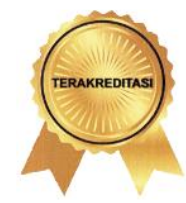

SINTA 2

\section{DOI : https://doi.org/10.24843/MATRIK:JMBK.2020.v14.i02.p08}

\begin{abstract}
ABSTRAK
Pertumbuhan jumlah penyedia layanan SPA searah dengan pertumbuhan potensi pasar pengguna layanan. Kondisi Pandemi Covid 19, menempatkan layanan SPA pada jenis layanan yang memiliki potensi resiko penularan relatif tinggi sehingga harus menerapkan prosedur pencegahan yang berdampak pada peningkatan biaya layanan, Penelitian ini bertujuan untuk memprediksi intensi konsumsi layanan SPA dari perspektif Theory of Planed Behavior dengan mempertimbangkan perceived risk. Berdasarkan data survei dari 390 konsumen pengguna layanan SPA di wilayah Kuta dan Ubud, hasil analisis regresi berganda mengungkapkan bahwa attitude, social norms, perceived behavioral control berpengaruh positif terhadap intensi konsumsi perawatan SPA. Perceived risk tidak signifikan berpengaruh terhadap intensi konsumsi perawatan SPA di masa tatanan era baru. Implikasi temuan ini merekomendasikan penyedia layanan SPA untuk mempertahankan attitude yang positif dan controlability individu terhadap layanan SPA dengan penerapan prosedur standar kesehatan secara konsisten dalam penyelenggaraan layanan SPA, mengkomunikasikan pada opinion leader maupun lembaga pemerintah upaya pencegahan penularan virus yang dilakukan. Penelitian selanjutnya disarankan menguji konsistensi temuan dengan memasukkan risk attitude atau individual involvement sebagai moderator dalam model konseptual.
\end{abstract}

Kata kunci: attitude, social norms, perceived behavioral control, perceived risk, intention to consume

\section{Analysis of Consumption of SPA Services in the New Era, Theory of Planned Behavior (TPB) Perspective}

\begin{abstract}
The number of SPA consumers, stimulated by positive growth of SPA industry 'till Pandemi hit Bali tourism as well as Global wellness tourism. Perceived risk of SPA treatment during Pandemi is higher and its demand fall. The objectives of present study are to predict intention to engage in a SPA treatment from Extended Planned Behavior Theory perspective with considering perceived risk. Data were accumulated from 390 respondents through on line survey, involved foreign SPA consumer in Ubud and Kuta. Results uncovered that attitude, subjective norms, perceived behavioral control positively significant affected intention to enggage in SPA treatment, while perceived risk statistically not significant influenced intention to enggage in SPA treatment. Implication of the finding is that SPA providers need to sanitize its service equipment and make its environment clean and hygienic to place SPA treatment on lower level of perceived risk. Future researches need to develop a contingent model of TPB which integrates individual attitude toward risk to test what role risk attitude has on the relationship among attitude, subjective norms, perceived behavioral control and intention to cocnsume SPA treatment. The role of individual involvement on the SPA treatment also needs to verify in the TPB model.
\end{abstract}

Keywords: attitude, subjective norms, perceived behavioral control, perceived risk 


\section{PENDAHULUAN}

SPA merupakan singkatan dari Solus Per Aqua, yang memiliki makna terapi air yang kemudian berkembang sebagai aktivitas perawatan kecantikan, perawatan tubuh, edukasi kesehatan, makanan sehat, makanan sehat yang biasanya dilaksanakan pada ruangan yang terletak dipusat keramaian seperti pertokoan, Mall, Hotel atau suatu tempat yang kusus untuk kegiatan wellness yang jauh dari keramaian kota. SPA merupakan segmen pasar wellness tourism dunia yang mengalami pertumbuhan yang positif. Publikasi Global Wellness Institute (2018) melaporkan volume pengguna SPA tumbuh $89 \%$ dengan peningkatan nilai belanja $86 \%$ dibandingkan periode 2017. Volume pengguna aktivitas wellness Indonesia tahun 2018 meliputi 8.335.200 orang, diantaranya $62 \%$ adalah wisatawan mancanegara. Sumbangan nilai belanja wellness activities di Indonesia tahun 2018 sebesar \$ 6.928.500 juta. Urgensi penelitian ini didasarkan pada potensi pertumbuhan segmen pasar wellness tourism dan sumbangan nilai ekonomi yang potential karena average spending wellness traveler 53\% lebih tinggi dibandingkan average spending Internasional Tourist, demikian pula belanja domestic wellness traveler yang mencapai $178 \%$ lebih tinggi dibandingkan average spending domestic tourist. Disisi lain kondisi pandemi saat ini menempatkan aktivitas wellness sebagai aktivitas yang dinilai beresiko dan berpotensi sebagai klaster penularan virus covid 19, sehingga berdampak pada penyelenggaraan kegiatan 1200 SPA provider yang beroperasi di Bali dengan pertumbuhan mencapai 45\% (Bisnis.Com, 28 Mei, 2018). Ayuningtyas dkk, (2019) melaporkan di wilayah Ubud, SPA provider berjumlah 283 terdiri dari Day SPA (187) dan Resort SPA/Hotel SPA/Villa SPA (96). Pelayanan SPA telah menarik perhatian beberapa peneliti selama ini. (Szromek \& Naramski, 2019) mengungkapkan bahwa layanan SPA meliputi akomodasi, makanan sehat, perawatan wajah, perawatan tubuh dan edukasi pola hidup sehat. Mak, Wong, \& Chang (2009) mengungkapkan bahwa tujuan melakukan perawatan SPA penduduk Hongkong mengkonsumsi layanan saat melakukan perjalanan wisata ke Luar Negeri adalah untuk relaxasi, penyembuhan, keluar dari rutinitas dan memanjakan diri sendiri.Alasan lain mengunjungi resort SPA adalah memelihara kesehatan, beristirahat dari rutinitas, memelihara kesehatan pisik dan mental, menghibur diri, bersosialisasi, memperkaya kegiatan wisata dan memperoleh pengalaman budaya dan spiritual (Szromek \& Naramski, 2019). Pasar SPA wisatawan Jepang dikategorikan dalam tujuh segmen berdasarkan tujuan mengunjungi destinasi SPA yaitu kelompok pengguna yang mencari keunikan pada destinasi SPA, kelompok kedua menemukan daya tarik dan kualitas SPA, kelompok ketiga untuk keluar dari rutinitas, kelompok keempat menemukan hubungan yang romantis, kelompok kelima untuk berolah raga, kelompok keenam untuk membangun hubungan kekeluargaan, kelompok ketujuh untuk membangun hubunngan dengan binatang peliharaan (Kamata, 2015). Fasilitas pelayanan yang dinilai penting oleh pelanggan dan mempengaruhi kepuasan pengguna SPA adalah tersedianya sarana akomodasi, sarana perawatan, perlengkapan, perlakuan sebagai tamu bukan sebagai pasien, ruang tidur tunggal, dilengkapi aktivitas budaya, sarana transportasi tamu, perawatan jiwa, sarana penitipan anak, kelas edukasi kesehatan bagi pengunjung dan sarana aktivitas spiritual (Bakirtzoglou \& Ioannou, 2018). Kualitas pelayanan SPA berkorelasi dengan emosi pelanggan. Daya tanggap dilaporkan sebagai dimensi kualitas yang paling kuat pengaruhnya terhadap emosi positif pelanggan, kemudian diikuti oleh reliability, empathy dan lingkungan pisik (Phil, 2010). Emosi pelanggan SPA dipicu oleh aspek pelayanan non pisik yang menstimuli sensasi pada lima indra pelanggan antara lain kebersihan, music, warna dan dekorasi ruang perawatan dan proses perawatan (Bakirtzoglou \& Ioannou, 2018). Kepuasan adalah salah satu bentuk attitude yang dibentuk dari pengalaman konsumsi individu dan merupakan hasil evaluasi positif kinerja elemen-elemen pelayanan SPA dalam memenuhi kebutuhan/harapan individu pelanggan (Seth et al., 2005). Kepuasan yang dialami individu dari perawatan SPA memediasi relakasi dengan positive word of mouth. Kajian penelitian terdahulu mengungkapkan bahwa motivasi konsumsi Layanan SPA tidak saja untuk 
memperoleh manfaat bagi pisik namun juga manfaat emosional, spiritual dan sosial. Emosi positif yang diperoleh dari layanan SPA merupakan elemen afektif yang timbul dari evaluasi lingkungan pelayanan yang dialami individu dan merupakan komponen attitude yang mempengaruhi intensi penggunaan layanan (Maria et al., 2013). Texas Medical Association mempublikasikan bahwa aktivitas perawatan rambut dan kecantikan menempati resiko level 7 dan kunjungan ke pusat kebugaran menempati resiko penularan level 8 diukur dari sekala 1-9. Kondisi ini tentu mempengaruhi persepsi resiko individu terhadap aktivitas perawatan SPA.

Memprediksi keberlanjutan sektor usaha SPA di era baru yang sering diistilahkan dengan era new normal, penting bagi praktisi, akademisi maupun pemegang kebijakan untuk memperoleh informasi bagaimana perceived risk perawatan SPA di era baru? Bagaimana pengaruh attitude individu, subjective norms, perceived controlability individu dan perceived risk pengguna layanan SPA dan terhadap intensi penggunaan SPA di era baru. Informasi intensi perawatan SPA di era baru menjadi masukan merancang strategi pemasaran produk dan layanan SPA di era baru. Keutamaan penelitian ini adalah memasukkan elemen resiko pisik, resiko sosial, resiko psikologis dan resiko waktu dalam model pengukuran perceived risk yang relevan dengan layanan SPA di Kehidupan Era Baru, memperluas kajian sebelumnya yang hanya memasukan dimensi esiko fungsional dan resiko finansial dalam pengukuran consumer perceived risk (C. Y. Lu et al., 2016).

\section{Planed Behavior Theory.}

Theory of Planned Behavior/TPB (Icek Ajzen, 1991) fokus mempelajari tindakan yang dilakukan secara sadar, berdasarkan pilihan individu atau merupakan keputusan individu. Teori TPB menyatakan bahwa attitude/sikap individu terhadap tindakan, norma subjektif dan persepsi pengendalian tindakan mempengaruhi intensi bertindak individu. Teori dispositional menyatakan bahwa tindakan individu dapat diprakirakan dari niat individu untuk bertindak. Perilaku/tindakan individu diawali oleh intensi/niat bertindak individu (Ajzen,1985). Attitude individu terhadap tindakan bisa bersifat positif atau negatif yang ditunjukkan oleh keyakinan individu terhadap manfaat dan mudarat tindakan tersebut. Norma subjektif direfleksikan oleh keyakinan normatif dan motivasi individu untuk mematuhi norma tersebut. Implementasi Theory of Planned Behavior dalam konteks penggunaan layanan SPA, mengukur attitude individu terhadap aspek layanan SPA meliputi manfaat, mudarat dan aktivitas serta sarana pelayanan SPA. Norma subjektif diukur berdasarkan norma lingkungan sosial individu yang memiliki ikatan maupun interaksi dengan intensitas tinggi seperti ayah, ibu, adik, kakak, sejawat dan pasangan terhadap aktivitas perawatan SPA. Perceived Behavioral control/Pengendalian tindakan diukur berdasarkan dimensi kemudahan individu untuk melaksanakan tidakan dan ketersediaan sumber daya waktu, finansial dan pisik untuk melaksanakan perawatan SPA.

Aplikasi Planned Behavior Theory telah diterapkan dalam berbagai konteks perilaku antara lain intensi menggunakan sistem pembiayaan Syaria dalam kepemilikan rumah yang mengungkapkan bahwa attitude, subjective norm, perceived behavioral control, level of knowledge or awareness and religiousity berkorelasi positif dengan customer's intention memilih metode keuangan Syaria dalam kepemilikan rumah (Jafarkarimi et al., 2016) (Ibrahim, M.A., Fisol,W.N. M., \& Haji- Othman,Y. 2017). Ayob, S. F. (2017) dan Nduneseokwu, C. K.,et al., (2017) pada kesempatan berbeda menerapkan TPB dalam konteks perilaku pemisahan sampah. Ayob, S. F.(2017) melaporkan bahwa attitude dan perceived behavioural control berkorelasi signifikan dan subjective Norms dilaporkan tidak signifikan pengaruhnya terhadap behavioral intention. Nduneseokwu,C.K.,et al.(2017) mengungkapkan bahwa ketersediaan sarana dan prasarana memoderasi hubungan attitude and subjective norms dengan behavioral intention pemisahan sampah organik dan anorganik. Braddock, $\mathrm{K}$ \& Dillard,J.P.(2016) melaporkan aplikasi Theory of Planned Behavior pada konteks perilaku 
berorientasi kesehatan dan menjelaskan bahwa perubahan attitude dimungkinkan melalui perubahan beliefts dan Norma sosial untuk membangun Self Efficacy dalam melaksanakan tindakan tertentu. Dahiya, R., \& Gayatri (2017) menerapkan dalam konteks penggunaan strategy komunikasi pemasaran digital pada pengambilan keputusan pembelian mobil di India dan melaporkan bahwa Attitude, subjective norms and perceived behavioural control signifikan pengaruhnya terhadap usage intentions dan actual usage pembeli mobil di India. (Loureiro et al., 2013) mengungkapkan bahwa intensi mengunjungi Hotel SPA dipengaruhi oleh atmosfer lingkungan pelayanan dan keterlibatan individu pelanggan secara signifikan.

Penelitian ini menambahkan konsep perceived risk dan mengintegrasikan dengan model TPB sebelumnya untuk mengukur perceived risk penggunaan layanan SPA dan pengaruhnya terhadap intensi penggunaan Layanan SPA. Model konseptual mengintegrasikan perceived risk dalam model dasar TPB disajikan pada gambar.1.

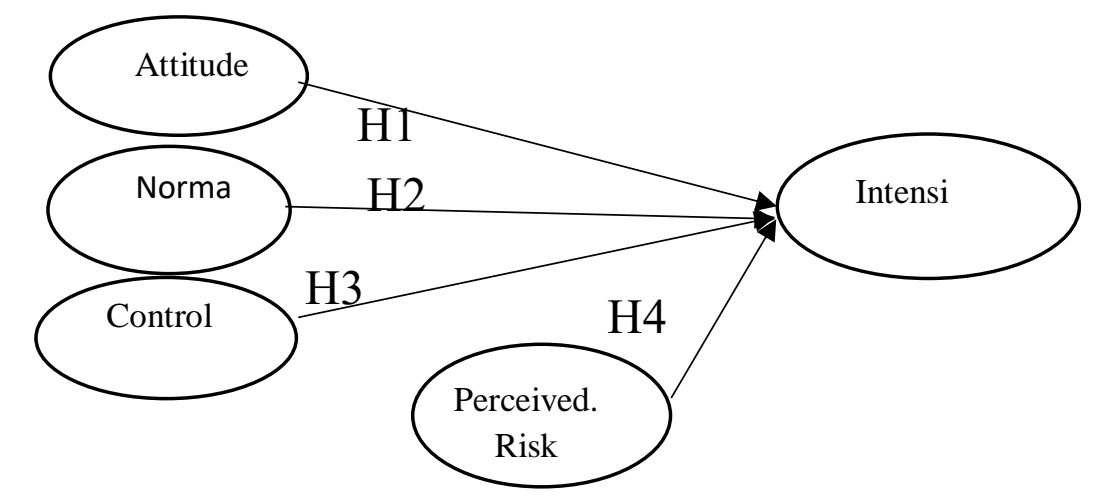

\section{Gambar 1. Model Konseptual penelitian}

\section{Attitude dan Intention to Consume SPA.}

Individu yang merencanakan melakukan tindakan tertentu biasanya melakukan evaluasi terhadap manfaat dan mudarat tindakan tersebut sebelum melakukannya (Allen et al., 1970). Attitude individu terhadap suatu tindakan merefleksikan pula tingkat kepentingan tindakan tersebut. Perilaku individu secara umum dibedakan menjadi dua kelompok yaitu mendekati tujuan/capaian positif dan menjauhi tujuan/capaian negatif. Sebagian konsumsi produk bertujuan untuk mencapai tujuan positif, sementara sebagian lain dikonsumsi untuk tujuan menjauhi kondisi/tujuan negatif (Noone \& Mattila, 2009). Attitude individu terbentuk secara implisit diluar kesadaran, karena kondisi lingkungan. Mengacu pada teori classical conditioning learning behavior, paparan pasangan objek yang ambigu dengan objek yang bernilai positif, cenderung membentuk attitude positif, sementara pasangan objek ambigu yang dengan objek negatif, cenderung dinilai negatif oleh individu. Attitude terhadap objek dapat dikondisikan ketika kesadaran individu relatif rendah pada lingkungan (Olson \& Fazio, 2001). Function Attitude Theory menyatakan bahwa, attitude memiliki beberapa fungsi psikologis yaitu fungsi ekspresi dan fungsi evaluasi. Attitude yang berfungsi evaluatif psikologis membentuk valensi dari karakteristik intrinsik objek attitude(Allen et al., 2000). Attitude yang berfungsi sebagai evaluasi psikologis membentuk interaksi orang dengan objek dan memberikan hasil yang terukur seperti reward and punishment (Allen et al., 2000). Sementara attitude yang berfungsi sebagai ekspresi nilai individu tidak menghasilkan valensi dari objek attitude, namun memberikan peningkatan self esteem ketika mengekspresikan attitude tersebut. Attitude juga dapat berfungsi sebagai social expression yang menghasilkan penerimaan/penolakan kelompok sosial. Attitude individu terhadap objek dipengaruhi oleh orientasi individu terhadap out group berkaitan dengan orientasi intrinsik atau orientasi ektrinsik individu. Ajzen,(2014) mengungkapkan bahwa attitude memiliki struktur kognitif, 
afektif dan konatif. Struktur kognitif adalah ekspresi keyakinan terhadap objek, struktur afektif merupakan ekspresi afektif dan struktur konatif adalah ekspresi behavioral intention. Dalam konteks Planned Behavior Theory, subjective norms memiliki karakteristik sebagai attitude yang berorientasi penerimaan sosial (Herek, 1987). Panadis, S., \& Phongvivat, L. (2011) melaporkan temuan bahwa:1) 56,5\% Pelanggan memiliki attitude positif terhadap Thai SPA; 2) $56 \%$ pelanggan merekomendasikan Thai SPA pada teman dan sejawat;3) 50\% pelanggan menjadikan Thai SPA sebagai pilihan pertama;4) $71 \%$ pelanggan menyatakan puas dengan pengalaman menggunakan Thai SPA dan 5) $70 \%$ pelanggan menyatakan akan menggunakan Thai SPA dimasa mendatang. Temuan ini mengungkapkan bahwa attitude yang positif terhadap Thai SPA disebabkan oleh kesesuaian layanan dengan layanan yang diharapkan pelanggan dan selanjutnya kepuasan pelanggan berkorelasi positif dengan kesediaan merekomendasikan Thai SPA dan intensi penggunaan kembali Thai SPA (Phongvivat \& Panadis, 2011). Dalam kontek komunikasi periklanan, Lim, Kim, \& Lee (2016) melaporkan bahwa elemen kognitif evaluatif lebih dominan mempengaruhi attitude terhadap iklan dibandingkan komponen afektif. Temuan penelitian yang dilakukan dengan melibatkan mahasiswa Taiwan dan China mengungkapkan, bahwa Environment knowledge berkorelasi positif dengan environment attitude dan environmental knowledge berkorelasi dengan environment behavioral intention. (Cui et al., 2016). Informasi yang membangun consumer green conciousness berkorelasi positif dengan green hotel attitude dan berkorelasi positif dengan intention to stay (Martinez Garcia de Leaniz, P.,2018). Affeksi dilaporkan memoderasi hubungan attitude dengan intensi perilaku berorientasi kesehatan (Mceachan, Hons, Taylor, Gardner, \& Conner (2016). Attitude berkorelasi positif dan signifikan dengan behavioral intention penggunaan food on time delivery delivery (Yeo et al., 2017). Tourists' local food attitudes berkorelasi positif dengan behavioral intentions to consume local food (Young et al., 2018). Attitude signifikan pengaruhnya terhadap behavioral intention dalam konsumsi halal food (Khalek \& Ismail, 2015). Dalam konteks pemberian Zakat, dilaporkan juga bahwa attitude berkorelasi signifikan dengan behavioral intention on zakat (Bidin, 2016) Pengaruh attitude individu terhadap intensi melakukan perawatan SPA dirumuskan sebagai berikut:

H1: Attitude terhadap perawatan SPA berpengaruh positif terhadap intensi konsumsi perawatan SPA.

\section{Subjective Norms dan Intention to Consume SPA}

Subjective norms didefinisikan sebagai persepsi tekanan sosial untuk melakukan tindakan terntentu atau tidak melakukan tindakan tertentu. Subjective norms dibentuk oleh Normative belieft yang berhubungan dengan Perceived Behavioral Control. Behavioral Belieft dihubungkan dengan Real Behavior berdasarkan aspek -aspek terkait behavioral outcome atau Behavioral cost. Normative Belieft adalah persepsi individu terhadap kuat/lemahnya persetujuan dari orang-orang penting/kelompok referensi dalam melaksanakan tindakan dan kepatuhan individu pada kelompok referensi tersebut. Ross \& Mclaws (1992) mengungkapkan bahwa subjective norms secara signifikan berpengaruh dengan Behavioral intention, bahkan lebih kuat sebagai prediktor behavioral intention. Secara terpisah Lin, Updegraff, \& Pakpour (2016) membuktikan juga bahwa norma subjektif berpengaruh signifikan terhadap intensi melakukan pengobatan pada pasien penderita epilepsi. Dalam konteks ecotourism, subjective norms secara signifikan mempengaruhi intention to visit (Thao et al., 2019). Subjective norms dilaporkan mepengaruhi intention to travel to Japan dikalangan remaja Taiwan (Hsieh et al., 2016). Subjective norms berpengaruh signifikan dalam penggunaan cloud technology (Ho, Ocasio-Velázquez, et al., 2017). Subjective norms berpengaruh signifikandengan intensi menyusui bayi para ibu muda (Bartle \& Harvey, 2017). Hipotesis hubungan subjective norms dengan behavioral intention konsumsi perawatan SPA adalah:

$\mathrm{H}$ 2: Subjective norms berpengaruh positif signifikan dengan intensi konsumsi perawatan SPA. 


\section{Perceived Behavioral Control dan Intention to Consume SPA.}

Perceived Behavioral Control diartikan sebagai persepsi kemudahan atau kesulitan melakukan tindakan. Persepsi ini dibentuk oleh pengalaman masa lalu dan antisipasi terhadap hambatan terkait tindakan tertentu. Dinyatakan bahwa semakin positive attitude, semakin kuat tekanan sosial dan semakin besar perceived behavioral control individu maka intensi bertindak individu cenderung semakin kuat. Dihubungkan dengan tindakan/perilaku nyata, semakin kuat intensi bertindak, semakin kuat daya prediksi perilaku nyata. Ajzen (1985) mengungkapkan pula bahwa intensi bukan satu-satunya prediktor perilaku nyata. perceived behavioral control merupakan prediksi intensi bertindak dan meningkatkan daya prediksi capaian dari tindakan (Ajzen, 1988). Faktor non motivasional seperti waktu, uang, kompetensi dan kerja sama, ditemukan mempengaruhi hubungan intensi dengan perilaku. Dalam penggunaan cloud technology, behavioral control dilaporkan signifikan pengaruhnya terhadap behavioral intention (Ho, Ocasio-Velázquez, et al., 2017). Dalam konteks medikasi penderita epilepsi, perceived behavioral control juga dilaporkan signifikan pengaruhnya terhadap behavioral intention (Lin et al., 2016). Perilaku networking menggunakan sosial media dilaporkan dipengaruhi pula oleh perceived behavioral control (Jafarkarimi et al., 2016). Dalam konteks konsumsi makanan organik, perceived behavioral control mempengaruhi behavioral intention secara positif dan signifikan (Johe \& Bhullar, 2016). Perceived behavioral control dibuktikan mempengaruhi behavioral intention dalam perilaku didalam restoran. Tidak semua individu berniat membaca label menu makanan karena pengetahuan tentang label makanan yang terbatas (Kim et al., 2013). Mengacu pada bukti empiris pengaruh perceived behavioral control dengan behavioral intention, hubungan pengaruh perceived behavioral control dengan intensi konsumsi perawatan SPA dirumuskan sebagai berikut:

H3: Perceived Behavioral Control berpengaruh signifikan dengan intensi konsumsi perawatan SPA.

\section{Perceived Risk dan Intention to Consume SPA.}

Perceived risk didefinisikan sebagai fungsi subjektif individu terkait peluang terjadinya peristiwa yang tidak diharapkan dan besarnya dampak peristiwa tersebut sebagai akibat konsumsi suatu produk ((Dowling \& Staelin, 1994). Resiko yang dihadapi konsumen meliputi resiko fungsional, resiko keuangan, resiko finansial, resiko sosial, resiko psikologis, resiko pisik dan resiko waktu. Resiko sosial adalah dampak konsumsi yang berkaitan dengan persetujuan lingkungan sosial individu konsumen. Resiko fungsional adalah dampak konsumsi berkaitan dengan kemampuan produk/jasa memenuhi kebutuhan/harapan individu konsumen. Resiko finansial dioperasionalkan sebagai dampak konsumsi yang berkaitan dengan kerugian finansial yang dialami individu konsumen. Resiko psikologis diartikan sebagai dampak konsumsi produk/jasa terhadap self concept individu konsumen. Resiko pisik adalah dampak konsumsi yang berkaitan dengan penurunan kualitas maupun fungsi pisik individu konsumen. Resiko waktu didefinisikan sebagai akibat yang ditimbulkan oleh keterlambatan penyerahan jasa. Pengukuran perceived risk dilakukan dengan pendekatan multi dimensi yaitu mengukur peluang terjadinya peristiwa yang tidak diharapkan dan mengukur besarnya dampak peristiwa tersebut (Dowling \& Staelin, 1994).

Loyalitas pelanggan merupakan suatu proses minimisasi resiko dalam pembelian yang dilakukan pelanggan terhadap kategori produk dalam jangka panjang (Marakanon \& Panjakajornsak, 2017). Hubungan perceived risk dengan perilaku loyal pelanggan restaurant dilaporkan oleh Merkebu (2015). Mitchell \& Greatorex, (1988) melaporka bahwa restaurant 
familiarity, staff friendliness dan restaurant reputation adalah elements of risk reduction strategy yang mendorong perilaku loyal konsumen wine (Lacey et al., 2009). Perilaku repeaters menunjukkan upaya mengurangi resiko konsumsi pada produk yang dinilai beresikotinggi. Jumlah repeaters pada kategori high risk product, lebih tinggi dibandingkan pada kelompok low risk product. Dalam jangka panjang jumlah repeaters kedua kelompok cenderung meningkat (Venkatesan, 1968). Loyalitas pada merek tertentu merupakan upaya menghindari ketidakpastian atau menghindari hasil yang tidak diinginkan. Penelitian sebelumnya terkait resiko konsumsi dan strategy minimisasi resiko konsumsi diteliti oleh (Mitchell \& Greatorex, 1988) yang mengungkapkan bahwa product trial, membaca label produk secara seksama, mengikuti panduan pemakaian, membeli produk dengan harga termurah, membeli produk dengan harga termahal dan mengandalkan citra produsen atau retailer adalah bentuk - bentuk strategi penghindaran resiko konsumsi. Persepsi resiko pengguna Hotel SPA di taiwan melaporkan bahwa perceived quality berkorelasi negatif dengan perceived risk Hotel SPA (I. Lu et al., 2011).

Tatanan Kehidupan Normal Baru mengharuskan setiap penyelenggara kegiatan layanan SPA hanya menggunakan 50\%-70\% kapasitas pelayanan untuk mengurangi kepadatan pelanggan dan meminimalkan penularan Covid 19. Kondisi ini dapat berdampak pada peningkatan biaya layanan, dampak kesehatan pisik individu pelanggan dan timbulnya kecemasan yang dialami individu pelanggan selama proses perawatan atau menimbulkan persepsi resiko psikologis. Penurunan kapasitas pelayanan juga berdampak pada penundaan layanan dan perpanjangan waktu menunggu sehingga menimbulkan resiko waktu.

Tatanan kehidupan era baru menjadi pertimbangan penelitian ini memasukkan elemen resiko konsumsi tambahan yang dinilai relevan dengan kondisi Pandemi saat ini yaitu resiko pisik, resiko psikologis, resiko sosial dan resiko waktu. Persepsi resiko pada produk pendukung pariwisata telah diteliti oleh beberapa peneliti. Intensi pembelian tiket pesawat dipengaruhi oleh perceived risk yang dikontruksikan oleh resiko keamanan, resiko privaci, resiko financial, performance risk dan psychological risk (Lee, 2009). Konsumen yang memiliki persepsi resiko relatif rendah atas produk atau jasa akan lebih mudah membangun kepercayaan dan meningkatkan intensi pembelian (Ha, 2020). Temuan penelitian dari lingkungan pengguna mobile travel booking, menyatakan bahwa percived risk bersifat multi dimensi yaitu time risk, financial risk, performance risk, privacy/security risk, psychological risk, physical risk dan device risk yang signifikan pengaruhnya terhadap penggunaan E-travel booking, dan social risk tidak menunjukkan pengaruh yang signifikan (Sangwon Park, Guildford, Surrey, 2019). Penggunaan mobile hotel application dipengaruhi oleh trust dan perceived risk terhadap mobile hotel booking application (Ozturk et al., 2017). Penelitian perilaku belanja online menemukan bahwa bahwa financial risk, product risk, security risk, psychological risk berkorelasi negatif dan signifikan dengan intention to purchase, sementara time risk dan social risk tidak berkorelasi signifikan dengan intention to purchase (Ariffin et al., 2018). Pengaruh perceived risk dengan intensi penggunaan perawatan SPA dirumuskan sebagai berikut:

H4: Perceived Risk Berpengaruh negatif dan signifikan terhadap intensi penggunaan perawatan SPA.

\section{METODE PENELITIAN}

Desain penelitian ini adalah survei yang melibatkan individu pengguna layanan SPA di wilayah Kuta dan Ubud. Jumlah sampel penelitian adalah 390 yang ditentukan berdasarkan formula jumlah populasi diasumsikan infinite, nilai alpha 0,05 dan $\mathrm{Z}=1$,96. Jumlah sampel yang diambil dari masing-masing wilayah proporsional, masing-masing $50 \%$.

$$
\text { Rumus : } \mathrm{n}=\frac{\mathrm{Z} \alpha^{2} \cdot \mathrm{p} \cdot \mathrm{q}}{\mathrm{D}^{2}}
$$




$$
\begin{aligned}
& \mathrm{n}=\frac{(1,96)^{2} \cdot 0,5 \cdot 0,5}{(0,05)^{2}} \\
& \mathrm{n}=385, \text { dibulatkan menjadi } 390 \text { responden. }
\end{aligned}
$$

Model konseptual penelitian dibangun dari empat variabel bebas dan satu variabel terikat. Variabel bebas adalah attitude, subjective Norms, Perceived behavioral control dan perceived risk, sementara variabel terikat adalah intensi menggunakan perawatan SPA. Variabel penelitian didefinisikan antara lain, Perceived risk didefinisikan sebagai persepsi individun terhadap peluang terjadinya peristiwa yang tidak diharapkan dalam perawatan SPA (Bitner, 1992). Pengukuran meliputi lima dimensi: financial risk, yaitu terkait dengan pengeluaran/kerugian yang disebabkan oleh pembelian/konsumsi SPA; functional risk, adalah persepsi kegagalan memperoleh manfaat dari konsumsi SPA; physical risk mengacu pada keamanan atas penggunaan produk atau jasa, sosial risk yaitu persetujuan gunakan perawatan SPA dari lingkungan sosial individu; time risk adalah persepsi ketidaktepatan waktu perawatan sebagaimana yang dijadwalkan dan psychological risk adalah persepsi individu terkait dampak konsumsi SPA terhadap self esteem individu (Chung et al., 2013; Maciejewski, 2011). Attitude dioperasionalkan berdasarkan dimensi manfaat dan penilaian individu terhadap manfaat perawatan SPA dan kualitas lingkungan perawatan. Subjective norms/Norma subjektif dioperasionalkan sebagai persetujuan atau dorongan dari dilingkungan individu yang berkaitan dengan manfaat dan mudarat konsumsi perawatan SPA. Perceived behavioral control didefinisikan sebagai persepsi individu terhadap hambatan dan kemudahan akses perawatan SPA dinilai dari dimensi ketersediaan waktu, sumber daya keuangan dan kondisi kesehatan pisik individu. Behavioral Intention konsumsi perawatan SPA didefinisikan sebagai niat individu untuk melakukan perawatan SPA.

Penelitian ini dilaksanakan melalui serangkaian prosedur yaitu: observasi untuk mengetahui fenomena dan aktivitas dan lingkungan pelayanan pada Industri Spa di Bali, mengidentifikasi indikasi masalah yang terkait attitude, subjectif norm, perceived behavioral control, perceived risk dan intensi melakukan perawatan SPA; pengkajian teori dan bukti empiris yang relevan, mengkontruksi model konseptual, merumuskan hipotesis penelitian, pengumpulan data, analisis data dan menyajikan laporan penelitian. Lokasi penelitian ini di wilayah Ubud dan Kuta karena Ubud dan Kuta merupakan destinasi utama yang menjadi tujuan 72\% wisatawan pada tahun 2019 (unpublished, Airport survei, BPPD Bali,2019).

Data penelitian ini terdiri dari data kuantitatif dan data kualitatif. Data kualitatif yang dikumpulkan antara lain jenis kelamin responden, subjective norms pelanggan, attitude pelanggan, perceived behavioralcontrol individu pelanggan dan perceived risk pelanggan SPA. Data kuantitatif penelitian ini antara lain usia responden dan frekuensi penggunaan layanan SPA. Data penelitian yang dikumpulkan dari sumber primer yaitu subjective norms pelanggan, attitude pelanggan, perceived behavioralcontrol individu pelanggan dan perceived risk pelanggan. Data penelitian yang dikumpulkan dari sumber sekunder publikasi organisasi pengelola destinasi atau asosiasi industri SPA antara lain, jumlah wisatawan yang berkunjung ke Bali tahun 2019, proporsi kunjungan wisatawan ke Ubud dan Kuta.

Data penelitian variabel attitude, subjective norms dan perceived behavioral control dan behavioral intention pelanggan diukur dengan mengacu pada instrumen yang dikembangkan oleh Ajzen, I. (2002). Data perceived risk diukur dengan instrumen yang dikembangkan oleh Brooker, G. 1984 and Bettman, J. R.(1973). Penyusunan instrumen data attitude, norma subjektif dan perceived behavioral control, perceived risk dan behavioral intention individu konsumsi perawaratan SPA dilakukan dengan sekala likert yang terdiri dari lima (5) interval yang mewakili pendapat 1 (sangat tidak setuju) -5 (sangat setuju). Validitas instrumen pengukuran data dilakukan dengan metode analisis Faktor Konfirmatori. Validitas model pengukuran berdasarkan besaran parameter Kaiser, Olkin dan Meyer min 0,51 dan nilai 
barlet's test $=0,51-1,0$. Validitas butir indikator pengukuran data ditetapkan berdasarkan besaran nilai Loading minimal 0,41 (Hair, tatam and Black, 2010). Reliabilitas instrumen pengukuran ditentukan berdasarkan besaran parameter Alpha cronbach minimal 0,60. Pengujian hipotesis penelitian dilakukan dengan metode analisis regresi berganda. Secara bertahap dilakukan uji regresi berganda dan verifikasi uji asumsi klasik meliputi uji normalitas data, uji multikoliniaritas data dan uji heteroskedastisitas. Uji autokorelasi tidak dilakukan karena tidak menggunakan data time series.

\section{HASIL DAN PEMBAHASAN}

Karakteristik sosial demografi responden penelitian disajikan pada Tabel 1. Total reponden yang terlibat adalah 390 yang dikumpulkan di wilayah kecamatan Kuta dan kecamatan Ubud. Proses pengumpulan data dilakukan dengan mendistribusikan instrumen pengukuran data (kuesioner) pada 400 pengguna layanan SPA di wilayah kecamatan Ubud dan Kecamatan Kuta masing-masing 200. Tingkat pengembalian 95\% yaitu 390 kuesioner.

Responden penelitian ini 62\% berasal dari Eropa, 18,3\% berasal dari Amerika, 11,7\% berasal dari Asia dan 7,5\% berasal dari Australia. Jenis kelamin responden 66,7\% adalah wanita dan sisanya laki-laki. Kelompok usia pengguna perawatan Spa terbanyak adalah yang berusia 21 - 40, sebesar $73,7 \%$ dan sisanya $22,1 \%$ berusia diatas 40 tahun sementara hanya sebagian kecil (5\%) berusia 20 tahun.

Pengguna perawatan Spa sebagian besar adalah pekerja swasta (54\%), pengusaha $(16,9 \%)$, Pegawai Pemerintah $(16,9 \%)$ dan pelajar hanya 13,2\%. Pendidikan pengguna perawatan Spa sebagian besar berpendidikan Sarjana (55,8\%), SMU (33,3\%), yang berpendidikan lebih rendah dari SMU $(0,5 \%)$ dan yang berpendidikan lebih tinggi dari Sarjana $5,6 \%$. Responden kebanyakan membelanjakan uangnya rata-rata per hari berkisar antara $\$ 210$ - \$600 sementara responden yang membelanjakan lebih besar dari \$600 adalah sebesar 15,5\% dan yang membelanjakan uangnya sebesar \$200 atau kurang sebesar 5,2\%. Responden mengunjungi Bali kebanyakan untuk berlibur $(68,5 \%)$, Bisnis $(18,8 \%)$, wisata kebugaran $(4,7 \%)$ dan lainnya $(8 \%)$. Responden telah memiliki pengalaman perawatan Spa minimal dua kali $(55,9 \%)$, tiga kali $(27,7 \%)$ dan lebih dari tiga kali $(16,4 \%)$. Hasil analisis deskriptif variabel sosial demografi responden disajikan pada Tabel 1.

Instrumen penelitian dinyatakan valid berdasarkan nilai parameter Keiser Meyer Olkin $<0,50$; Barlett test bernilai 0,50 -1,0 dan total variance explained $=0,50<$ untuk faktor yang memiliki nilai eigen $=1,0<$. Reliabilitas data penelitian dinilai berdasarkan besaran Alpha Cronbach yang bernilai sama dengan/lebih besar dari 0,60. Berdasarkan hasil uji yang dilakukan dengan metode analisis faktor konfirmatori dan metode scale intrumen dinilai memadai dan data penelitian dinyatakan valid serta reliable. Hasil uji validitas dan reliabilitas secara disajikan pada Tabel 2.

Pengujian hipotesis yang dilakukan dengan metode regresi berganda menghasilkan model regresi:

$$
\begin{aligned}
& \text { Intensi }=3,629+0,038 \text { attitude+ 0,270 Subjective norm - 0,09 Perceived }
\end{aligned}
$$

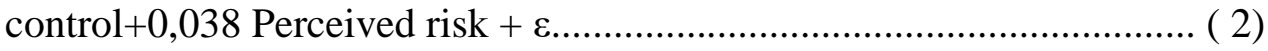


Tabel 1. Karakteristik Demografi Responden

\begin{tabular}{|c|c|c|c|}
\hline \multirow{2}{*}{ No } & \multirow{2}{*}{ Karakteristik Responden } & \multicolumn{2}{|c|}{ Jumlah } \\
\hline & & Orang & $(\%)$ \\
\hline & Negara Asal Responden & & \\
\hline 1 & Amerika & 71 & $18,3 \%$ \\
\hline 2 & Eropa & 243 & $62,5 \%$ \\
\hline 3 & Australia & 30 & $7,5 \%$ \\
\hline \multirow[t]{3}{*}{4} & Asia & 46 & $11,7 \%$ \\
\hline & Total & 390 & $100 \%$ \\
\hline & Jenis Kelamin Responden & & \\
\hline 1 & Pria & 140 & $33,3 \%$ \\
\hline \multirow[t]{3}{*}{2} & Wanita & 260 & $66,7 \%$ \\
\hline & Total & 390 & $100 \%$ \\
\hline & Kelompok Usia Responden & & \\
\hline 1 & $11-20$ & 17 & $4,2 \%$ \\
\hline 2 & $21-30$ & 139 & $35,7 \%$ \\
\hline 3 & $31-40$ & 148 & $38,0 \%$ \\
\hline 4 & $41-50$ & 70 & $18,3 \%$ \\
\hline \multirow[t]{3}{*}{5} & $>51$ & 16 & $3,8 \%$ \\
\hline & Total & 390 & $100 \%$ \\
\hline & Pekerjaan Responden & & \\
\hline 1 & Pegawai Negeri & 66 & $16,9 \%$ \\
\hline 2 & Pegawai Swasta & 210 & $54,0 \%$ \\
\hline 3 & Pengusaha & 66 & $16,9 \%$ \\
\hline 4 & Pelajar & 28 & $7,0 \%$ \\
\hline \multirow[t]{3}{*}{5} & Lainnya & 20 & $5,2 \%$ \\
\hline & Total & 390 & $100 \%$ \\
\hline & Tingkat Pendidikan Responden & & \\
\hline 1 & $<\mathrm{SMU}$ & 20 & $0,5 \%$ \\
\hline 2 & SMU & 130 & $33,3 \%$ \\
\hline 3 & S1 & 218 & $55,8 \%$ \\
\hline \multirow[t]{3}{*}{4} & $>\mathrm{S} 1$ & 22 & $5,6 \%$ \\
\hline & Total & 390 & $100 \%$ \\
\hline & Pengeluaran Responden per Hari & & \\
\hline 1 & $<\$ 200$ & 20 & $5,2 \%$ \\
\hline 2 & $\$ 210-\$ 400$ & 132 & $33,8 \%$ \\
\hline 3 & $\$ 410-\$ 600$ & 177 & $45,5 \%$ \\
\hline 4 & $\$ 610-\$ 800$ & 55 & $14,1 \%$ \\
\hline \multirow[t]{3}{*}{5} & $>\$ 800$ & 6 & $1,4 \%$ \\
\hline & Total & 390 & $100 \%$ \\
\hline & Motivasi Kunjungan & & \\
\hline 1 & Berlibur & 267 & $68,5 \%$ \\
\hline 2 & Wisata kesehatan atau kebugaran & 19 & $4,7 \%$ \\
\hline 3 & Bisnis & 73 & $18,8 \%$ \\
\hline \multirow[t]{3}{*}{4} & Lainnya & 31 & $8,0 \%$ \\
\hline & Total & 390 & $100 \%$ \\
\hline & Frekuensi Konsumsi Perawatan Spa & & \\
\hline 1 & Dua kali & 218 & $55,9 \%$ \\
\hline 2 & Tiga kali & 108 & $27,7 \%$ \\
\hline \multirow[t]{2}{*}{3} & Lebih dari tiga kali & 64 & $16,4 \%$ \\
\hline & Total & 390 & $100 \%$ \\
\hline
\end{tabular}

Sumber: Data penelitian, 2020 
Tabel 2 Validitas dan Reliabilitas Instrumen

\begin{tabular}{lrll}
\hline \multicolumn{1}{c}{ Variabel } & $\begin{array}{l}\text { Jumlah } \\
\text { Item }\end{array}$ & $\begin{array}{l}\text { Cronbach } \\
\text { Alpha }\end{array}$ & $\begin{array}{l}\text { Total Varian } \\
\text { Explained }\end{array}$ \\
\hline Attitude & 4 & 0,750 & 0,703 \\
\hline Subjective Norm & 4 & 0,815 & 0,808 \\
\hline Perceived Behavioural Control & 6 & 0,762 & 0,762 \\
\hline Perceived Risk & 13 & 0,758 & 0,754 \\
\hline Behavioural Intention & 3 & 0,732 & 0,680 \\
Sumber: Data Penelitian,2020 & &
\end{tabular}

Pengujian asumsi normalitas data, multikoliniaritas dan heteroskedastisitas menunjukkan tidak terjadi pelanggaran asumsi. Hasil uji normalitas, multikoliniaritas dan heteroskedastisitas disajikan pada Tabel 3.

Tabel 3. Hasil Uji Normalitas, Multikoliniaritas Dan Heteroskedastisitas

\begin{tabular}{llllcc}
\hline No & Variabel & Normalitas & \multicolumn{2}{c}{ Multikoliniaritas } & Heterkedastisitas \\
\hline 1 & Attitude & (K-S) & Tolerance & VIF & (Glejser) \\
\hline 2 & Subjective Norm & 0,0653 & 0,682 & 1,466 & 0,0653 \\
\hline 3 & Perceived Risk & 0,0641 & 0,674 & 1,483 & 0,0785 \\
\hline 4 & Behavioural Intention & 0,0573 & 0,822 & 1,217 & 0,0556 \\
\hline
\end{tabular}

Sumber: Data Penelitian, 2020

Hasil uji hipotesis menunjukkan bahwa model pengaruh attitude, subjective norms, perceived control dan perceived risk valid dalam memprediksi intensi penggunaan jasa perawatan SPA, menunjukkan koeffisien determinasi $(\mathrm{R} 2)=26,9 \%$, yang artinya bahwa variasi intensikonsumsi perawatan SPA sebesar 26,9\% dipengaruhi oleh attitude, subjective norms, perceived control dan perceived risk. $73,1 \%$ dipengaruhi oleh variabel lain yang tidak dimasuukkan dalam model regressi. Validitas model Regresi dinilai memadai $\left(\mathrm{F}_{(4,385)}=\right.$ 35,465 ; p,0,05). Hasil analisis partial dinilai dari parameter Standardized Coefficient Beta, mengungkapkan bahwa attitude individu terhadap intensi penggunaan perawatan SPA signifikan ( $\beta=0,324 ; \mathrm{t}=6,141 ; \mathrm{p}<0,05)$, demikian pula dengan pengaruh subjective norms; $(\beta=0,143 ; t=2,702 ; p<0,05)$, perceived behavioral control $\quad(\beta=0,181 ; t=3,756 ; p<0,05)$. Pengaruh perceived risk tidak signifikan secara statistik $(\beta=0,30 ; \mathrm{t}=-0,674 ; \mathrm{p}>0,05)$. Dalam model regresi hanya pengaruh perceived risk yang tidak signifikan terhadap dengan intensi konsumsi perawatan SPA, sementara attitude, perceived behavioral control dan subjective norms berpengaruh positif dan signifikan. Parameter hasil analisis regresi secara rinci disajikan pada Tabel 4. Hasil Uji hipotesis menjelaskan berdasarkan perspektif Theory of Planned Behavior yang diitegrasikan dengan perceived risk untuk memprediksi intensi konsumsi perawatan SPA yang diputuskan secara sadar dan dalam kendali individu.

Attitude adalah penilaian individu terhadap manfaat dan mudarat perawatan SPA dan menjadi pertimbangan yang paling kuat dalam mempengaruhi intensi penggunaan perawatan SPA. Temuan ini serupa dengan temuan yang dilaporkan oleh Sobh, R., \& Martin, B. A (2011) yang menyatakan bahwa tindakan tertentu dilakukan individu untuk memenuhi tujuan positif 
atau menjauhi kondisi negatif. Mengkomunikasikan manfaat perawatan SPA dapat membentuk sikap individu yang lebih kuat terhadap perawatan SPA (Olson, M. A., \& Fazio, R. H.,2001). Menonjolkan informasi positif perawatan SPA dapat membentuk sikap positif individu pelanggan SPA meliputi kualitas lingkungan pelayanan, peralatan dan perawatan SPA yang digunakan dan prosedur sanitasi yang diterapkan. Mengkomunikasikan manfaat perawatan SPA secara luas bahwa mengkonsumsi perawatan SPA bermanfaat untuk menyehatkan, memelihara kebugaran tubuh, relaxasi, meredakan kepenatan dan memberikan kesegaran dapat membangun sikap positif individu terhadap perawatan SPA.

Tabel 4. Hasil Analisis Regresi

\begin{tabular}{|c|c|c|c|c|c|}
\hline Model & $\begin{array}{l}\text { Unstandardized } \\
\text { B }\end{array}$ & $\begin{array}{l}\text { Coefficient } \\
\text { Std. Error }\end{array}$ & $\begin{array}{l}\text { Std. Coeff } \\
\text { Beta }\end{array}$ & $\mathrm{t}$ & Sig. \\
\hline Konstanta & 3,629 & 0,527 & & 6,884 & 0,000 \\
\hline Attitude & 0,270 & 0,044 & 0,324 & 6,141 & 0,000 \\
\hline Subjective norms & 0,038 & 0,014 & 0,143 & 2,702 & 0,007 \\
\hline $\begin{array}{l}\text { Perceived Behav. } \\
\text { Control }\end{array}$ & 0,038 & 0,010 & 0,181 & 3,756 & 0,000 \\
\hline Perceived risk & $-0,090$ & 0,014 & $-0,300$ & $-\overline{0}, 674$ & 0,501 \\
\hline $\begin{array}{l}\text { Coeff.Determination }\left(R^{2}\right) \\
\text { Validitas Model Regresi }\end{array}$ & $\mathrm{F}_{(4.385)}=35,465: \mathrm{p}$ & 05 & & & 0,269 \\
\hline
\end{tabular}

Subjective norms merupakan nilai - nilai sosial yang berlaku dilingkungan tertentu yang disosialisasikan oleh orang-orang/lembaga yang memiliki kredibilitas di lingkungan tersebut. dan berfungsi sebagai pedoman kelayakan bertindak. Lembaga pemerintah, asosiasi profesi orang tua, teman-teman, pasangan baik suami maupun istri merupakan individu yang memiliki interaksi dalam intensitas tinggi dengan individu responden yang memberikan pengaruh dalam bentuk dorongan atau hambatan dalam melakukan tindakan menggunakan perawatan SPA. Pasangan responden baik suami atau istri berperan mendorong atau menghambat perilaku penggunaan perawatan SPA dengan alasan kesehatan atau penghematan sumber daya keuangan di masa Pandemi. Temuan penelitian ini menunjukkan bahwa subjective norms berpengaruh positif dan signifikan terhadap intensi konsumsi perawatan SPA. Temuan penelitian ini tidak berbeda dengan temuan Lin, C. Y., Updegraff, J. A., \& Pakpour, A. H., (2016); Khalek, A. A., Ismail, S. H. S., \& Ibrahim, H. M. 2017; Choe, J. Y. J., \& Kim, S. S.,(2018) pada konteks konsumsi local food, halal food, penggunaan metode keuangan syariah dan pengobatan pasien epilepsi. Peran lingkungan dan orang terdekat yang dianggap penting oleh individu signifikan pengaruhnya terhadap keputusan bertindak individu. Temuan ini menunjukkan bahwa peran asosiasi penyedia layanan SPA maupun individu yang dianggap penting oleh individu memiliki pengaruh signifikan terhadap intensi konsumsi perawatan SPA. Implikasi temuan ini merekomendasikan bahwa komunikasi tentang manfaat, kualitas dan sanitasi sarana dan prasarana yang digunakan dalam proses perawatan SPA dikomunikasikan dan disosialisasikan pada pihak-pihak yang memiliki legitimasi dalam masyarakat dan individu yang berperan sebagai opinion leader dalam komunitas karena mereka memiliki kemampuan untuk mempengaruhi intensi konsumsi SPA individu melalui penerimaan sosial untuk tindakan yang selaras dengan norma sosial yang berlaku.

Hasil analisis data juga mengungkapkan perceived behavioral control berpengaruh positif dan signifikan terhadap intensi penggunaan perawatan SPA. Temuan ini menjelaskan bahwa ketersediaan uang, ketersediaan waktu, penerapan prosedur pencegahan penularan covid 19, disiplin individu melaksanakan prosedur kesehatan, dan persepsi kondisi kesehatan 
individu merupakan indikator perceived behavioral control yang signifikan, serupa dengan temuan yang dilaporkan oleh Jafarkarimi, H. et al.,(2016). Faktor sumber daya yang mempengaruhi perceived behavioral control individu juga dilaporkan Johe \& Bhullar, (2016) dan Kim et al.,(2013). Pengaruh Perceived risk menunjukkan arah yang negatif terhadap intensi konsumsi perawatan SPA meskipun secara statistik tidak signifikan. Temuan ini mengungkapkan bahwa tidak semua responden pengguna perawatan SPA yang mempersepsikan perawatan SPA memiliki resiko tinggi, memiliki intensi konsumsi perawatan SPA rendah. Meskipun paerawatan SPA dinilai beresiko tinggi pada kondisi era baru namun mereka memiliki intensi konsumsi perawatan SPA yang relatif tinggi atau tetap menggunakan perawatan SPA di era baru. Resiko perawatan SPA menurut responden dipicu oleh lingkungan perawatan yang kurang sehat, peralatan yang digunakan, sanitasi sarana perawatan dinilai berpotensi menularan virus covid19 di lingkungan perawatan SPA dan ketersediaan biaya dan sarana perawatan untuk pemulihan bila terinfeksi. Keterbatasan sarana pelayanan memicu potensi penularan virus melalui peralatan perawatan dan terjadi penundaan pelayanan. Semakin tinggi perceived risk maka intensi penggunaan perawatan SPA cenderung maikin rendah. Temuan penelitian ini menjelaskan bahwa tidak semua pengguna layanan SPA membatalkan niat nya untuk menggunakan layanan SPA meskipun persepsi resiko perawatan SPA dinilai meningkat pada kondisi "era baru". Penelitian sebelumnya terkait perceived risk menjelaskan bahwa perceived risk terdiri dari dua dimensi yaitu dimensi objektif dan dimensi subjektif. Dimensi obyektif adalah peluang terjadinya penularan pada lokasi perawatan SPA yang dapat diperoleh dari data yang melaporkan pusat perawatan SPA sebagai kluster penularan covid 19. Dimensi subjektif perceived risk adalah persepsi subjektif indiividu terhadap tingkat resiko penularan virus pada pusat perawatan SPA. Individu memiliki dimensi resiko subjektif yang kas yang disebut dengan risk attitude. Prospect theory menjelaskan bahwa kepekaan individu dalam menghadapi pertambahan resiko untuk mencapai tujuan konsumsi bervariasi. Kelompok individu risk preferent memiliki toleransi terhadap resiko yang lebih besar dibandingkan kelompok pelanggan yang memiliki karakteristik risk aversive. Dengan demikian, kelompok pelanggan yang memiliki karakteristik risk preferent cenderung memiliki intensi mengkonsumsi perawatan layanan SPA lebih tinggi dibandingkan kelompok pelanggan yang memiliki karakteristik risk aversive pada kondisi tatanan era baru. Penelitian ini tidak memasukkan variabel risk Attitude individu responden dalam model. Pengaruh perceived risk yang tidak signifikan terhadap Behavioral intention serupa dengan temuan penelitian Chopdar, P. K., et al., (2018) pada pengguna mobile shopping apps dan Park, S., \& Tussyadiah, I. P. (2017) dari temuan penelitian intensi penggunaan mobile travel booking.

Peningkatan perceived risk responden tidak selalu menurunkan intensi penggunaan perawatan SPA. Data penelitian ini dikumpulkan dari responden asing melalui google form yang kebanyakan berasal dari Eropa. Penelitian ini tidak mengukur risk attitude individu responden. Kemungkinan bahwa individu yang memiliki karakteristik risk preferent lebih berani dalam menghadapi resiko dari tindakannya, sehingga meskipun mereka mempersepsikan bahwa melaksanakan perawatan SPA dimasa Pandemi meningkatkan resiko penularan covid 19 namun intensi individu untuk melakukan perawatan SPA lebih tinggi, sementara kelompok individu yang memiliki karakteristik Risk aversive memiliki intensi konsumsi perawatan SPA yang lebih rendah. Bagi kelompok individu Risk aversive peningkatan resiko perawatan SPA menurunkan intensi melakukan perawatan SPA. Penelitian berikutnya disarankan memasukkan variabel risk attitude sebagai moderator hubungan attitude, perceived behavioral control dan subjective norms dan perceived risk perawatan SPA dengan intensi konsumsi perawatan SPA untuk menguji apakah efek perceived risk hanya berdampak hanya untuk kelompok Risk averse dan tidak cukup kuat mempengaruhi kelompok individu yang memiliki karakteristik risk preferent atau berlaku sama baik bagi individu risk preferent maupun Risk averse. 


\section{SIMPULAN}

Hasil penelitian ini membuktikan dan memperkaya bukti empiris aplikasi Theory of Planned Behavior dari lingkungan pengguna perawatan SPA dengan menambahkan variabel perceived risk konsumsi perawatan SPA pada model. Hasil analisis data mengungkapkan bahwa attitude, subjective norms dan perceived behavioral control berpengaruh positif dan signifikan terhadap intensi pengunaan perawatan SPA. Perceived risk meskipun tidak signifikan secara statistik berpengaruh negatif terhadap intensi konsumsi pelayanan SPA.

Penggunaan google form dalam survei online memberikan resiko bahwa responden bukan individu yang memiliki kriteria target populasi yang ditetapkan. Penggunaan google form dalam survei memerlukan tindakan tambahan untuk validasi kesesuaian kriteria responden dengan kebutuhan. Pengguna layanan perawatan SPA yang berasal dari mancanegara memiliki karakteristik yang berbeda dengan pengguna layanan SPA yang berasal dari Indonesia. Penelitian berikutnya disarankan mereplikasi model penelitian ini menggunakan responden wisatawan Nusantara yang memiliki karakteristik sosial psikologi berbeda dengan responden wisatawan mancanegara. Responden wisatawan Nusantara sebagai masyarakat yang memiliki budaya komunalistik dan penghindar resiko tinggi (high risk avoidance) disarankan untuk dilibatkan sebagai responden pada penelitian berikutnya untuk menguji konsistensi temuan, kususnya menguji pengaruh relatif subjective norms dibandingkan dengan pengaruh attitude dan perceived behavioral control terhadap intensi penggunaan perawatan SPA. Penelitian sebelumnya melaporkan bahwa perceived risk dapat berperan memoderasi hubungan attitude, Norma subjective dan Perceived behavioral control dengan behavioral intention (Ho, Ocasio, et al., 2017). Penelitian selanjutnya dapat mengembangkan contingent model hubungan attitude, subjective norms dan perceived behavioral control terhadap intensi konsumsi perawatan SPA dengan memasukkan variabel risk attitude atau variabel perceived risk sebagai variabel moderator dalam model konseptual untuk memperkaya kajian empiris peran perceived risk dalam intensi konsumsi perawatan SPA di era kehidupan baru.

\section{REFERENSI}

Ajzen, I. (1989). Attitude structure and behavior. Attitude Structure and Function, JANUARY 1989, 241-274.

Ajzen, I. (1991). The Theory of Planned Behavior Organizational Behavior and Human Decision Processes. Organizational Behavior and Human Decision Processes, 50(2), 179-211.

Allen, M. W., Hung Ng, S., \& Wilson, M. (2002). A functional approach to instrumental and terminal values and the value-attitude-behaviour system of consumer choice. European Journal of Marketing, 36(1/2), 111-135. https://doi.org/10.1108/03090560210412728

Átha Cliath, B. (2011). "Consumer Attitude toward Spa in Thailand." Malardalen University Sweden, 06(June), 52-54.

Ayob, S. F., Sheau-Ting, L., Abdul Jalil, R., \& Chin, H. C. (2017). Key determinants of waste separation intention: empirical application of TPB. Facilities, 35(11-12), 696-708. https://doi.org/10.1108/F-06-2016-0065

Ayuningtyas, A. F., Widyatmaja, I. G. N., \& Sulistyawati, A. S. (2019). Strategi Pemasaran Untuk Meningkatkan Tingkat Penjualan Produk di Sang Spa Ubud Bali. 3(1), 195-210.

Bartle, N. C., \& Harvey, K. (2017). Explaining infant feeding: The role of previous personal and vicarious experience on attitudes, subjective norms, self-efficacy, and breastfeeding outcomes. British Journal of Health Psychology, 22(4), 763-785. https://doi.org/10.1111/bjhp.12254 
Bettman, J. R. (1979). Information processing theory of consumer choice. Addison-Wesley Pub. Co..

Bidin, Z., Deraman, M. J., \& Othman, M. Z. (2016). the Realtionships Among Attitude, Subjective Norm and. December, 1-7.

Bitner, M. J., Booms, B. H., \& Tetreault, M. S. (1990). The Service Encounter: Diagnosing Favorable and. 54(January), 71-84.

Chen, Z., Lan, Y., \& Zhao, R. (2018). Impacts of risk attitude and outside option on compensation contracts under different information structures. Fuzzy Optimization and Decision Making, 17(1), 13-47. https://doi.org/10.1007/s10700-016-9263-7

Cui, F., Liu, Y., Chang, Y., Duan, J., \& Li, J. (2016). An overview of tourism risk perception. Natural Hazards, 82(1), 643-658. https://doi.org/10.1007/s11069-016-2208-1

Dahiya, R., \& Gayatri. (2017). Investigating Indian Car Buyers' Decision to Use Digital Marketing Communication: An Empirical Application of Decomposed TPB. Vision, 21(4), 385-396. https://doi.org/10.1177/0972262917733175

Dowling, G. R., \& Staelin, R. (1994). A Model of Perceived Risk and Intended Risk-Handling Activity. Journal of Consumer Research, 21(1), 119. https://doi.org/10.1086/209386

Geng, L., Liu, T., Zhou, K., \& Yang, G. (2018). Can power affect environmental risk attitude toward nuclear energy? Energy Policy, 113(March), 87-93. https://doi.org/10.1016/j.enpol.2017.10.051

Ha, N. T. (2020). The impact of perceived risk on consumers' online shopping intention: An integration of TAM and TPB. Management Science Letters, 10(9), 2029-2036. https://doi.org/10.5267/j.msl.2020.2.009

Herek, G. (1987). Religious Orientation and Prejudice: A Comparison of Racial and Sexual Attitudes. Personality and Social Psychology Bulletin, 13(1), 34-44. https://doi.org/10.1177/0146167287131003

Ho, S. M., Ocasio-Velázquez, M., \& Booth, C. (2017). Trust or consequences? Causal effects of perceived risk and subjective norms on cloud technology adoption. Computers and Security, 70, 581-595. https://doi.org/10.1016/j.cose.2017.08.004

Hsieh, C. M., Park, S. H., \& McNally, R. (2016). Application of the Extended Theory of Planned Behavior to Intention to Travel to Japan Among Taiwanese Youth: Investigating the Moderating Effect of Past Visit Experience. Journal of Travel and Tourism Marketing, 33(5), 717-729. https://doi.org/10.1080/10548408.2016.1167387

Jafarkarimi, H., Saadatdoost, R., Sim, A. T. H., \& Hee, J. M. (2016). Behavioral intention in social networking sites ethical dilemmas: An extended model based on Theory of Planned Behavior. Computers in Human Behavior, 62, 545-561. https://doi.org/10.1016/j.chb.2016.04.024

Jin, N. (Paul), Line, N. D., \& Merkebu, J. (2016). The Impact of Brand Prestige on Trust, Perceived Risk, Satisfaction, and Loyalty in Upscale Restaurants. Journal of Hospitality Marketing and Management, 25(5), 523-546. https://doi.org/10.1080/19368623.2015.1063469

Johe, M. H., \& Bhullar, N. (2016). To buy or not to buy: The roles of self-identity, attitudes, perceived behavioral control and norms in organic consumerism. Ecological Economics, 128, 99-105. https://doi.org/10.1016/j.ecolecon.2016.02.019

Kamalul Ariffin, S., Mohan, T., \& Goh, Y. N. (2018). Influence of consumers' perceived risk on consumers' online purchase intention. Journal of Research in Interactive Marketing, 12(3), 309-327. https://doi.org/10.1108/JRIM-11-2017-0100

Khalek, A. A., \& Ismail, S. H. S. (2015). Why Are We Eating Halal - Using the Theory of Planned Behavior in Predicting Halal Food Consumption among Generation $Y$ in Malaysia. International Journal of Social Science and Humanity, 5(7), 608-612. https://doi.org/10.7763/ijssh.2015.v5.526 
Kim, E., Ham, S., Yang, I. S., \& Choi, J. G. (2013). The roles of attitude, subjective norm, and perceived behavioral control in the formation of consumers' behavioral intentions to read menu labels in the restaurant industry. International Journal of Hospitality Management, 35, 203-213. https://doi.org/10.1016/j.ijhm.2013.06.008

Lacey, S., Bruwer, J., \& li, E. (2009). The role of perceived risk in wine purchase decisions in restaurants. International Journal of Wine Business Research, 21(2), 99-117. https://doi.org/10.1108/17511060910967962

Lim, Y. J., Kim, H. K., \& Lee, T. J. (2016). Visitor Motivational Factors and Level of Satisfaction in Wellness Tourism: Comparison Between First-Time Visitors and Repeat Visitors. Asia Pacific Journal of Tourism Research, 21(2), 137-156. https://doi.org/10.1080/10941665.2015.1029952

Lin, C. Y., Updegraff, J. A., \& Pakpour, A. H. (2016). The relationship between the theory of planned behavior and medication adherence in patients with epilepsy. Epilepsy and Behavior, 61, 231-236. https://doi.org/10.1016/j.yebeh.2016.05.030

Loureiro, S. M. C., Almeida, M., \& Rita, P. (2013). The effect of atmospheric cues and involvement on pleasure and relaxation: The spa hotel context. International Journal of Hospitality Management, 35, 35-43. https://doi.org/10.1016/j.ijhm.2013.04.011

Lu, C. Y., Yeh, W. J., \& Chen, B. T. (2016). The Study of International Students' Behavior Intention for Leisure Participation: Using Perceived Risk as a Moderator. Journal of Quality Assurance in Hospitality and Tourism, 17(2), 224-236. https://doi.org/10.1080/1528008X.2015.1115267

Lu, I. Y., \& Shiu, J. Y. (2011). Decision-making framework of customer perception of value in Taiwanese spa hotels. Social Behavior and Personality, 39(9), 1183-1192. https://doi.org/10.2224/sbp.2011.39.9.1183

Mak, A. H. N., Wong, K. K. F., \& Chang, R. C. Y. (2009). Health or self-indulgence_The motivations and characteristics of spa-goers (PDF Download Available).pdf. 199(December 2008), 185-199.

Marakanon, L., \& Panjakajornsak, V. (2017). Perceived quality, perceived risk and customer trust affecting customer loyalty of environmentally friendly electronics products. Kasetsart Journal of Social Sciences, 38(1), 24-30. https://doi.org/10.1016/j.kjss.2016.08.012

Martínez Caro, L., \& Martínez García, J. A. (2008). Developing a multidimensional and hierarchical service quality model for the travel agency industry. Tourism Management, 29(4), 706-720. https://doi.org/10.1016/j.tourman.2007.07.014

McEachan, R., Taylor, N., Harrison, R., Lawton, R., Gardner, P., \& Conner, M. (2016). MetaAnalysis of the Reasoned Action Approach (RAA) to Understanding Health Behaviors. Annals of Behavioral Medicine, 50(4), 592-612. https://doi.org/10.1007/s12160-0169798-4

Mitchell, V. W., \& Greatorex, M. (1988). Consumer Risk Perception in the UK Wine Market. European Journal of Marketing, 22(9), 5-15. https://doi.org/10.1108/EUM0000000005296

Nduneseokwu, C. K., Qu, Y., \& Appolloni, A. (2017). Factors influencing consumers' intentions to participate in a formal e-waste collection system: A case study of Onitsha, Nigeria. Sustainability (Switzerland), 9(6), 1-17. https://doi.org/10.3390/su9060881

Noone, B. M., \& Mattila, A. S. (2009). Consumer reaction to crowding for extended service encounters. Managing Service Quality, 19(1), 31-41. https://doi.org/10.1108/09604520910926791

Olson, M. A., \& Fazio, R. H. (2001). Implicit attitude formation through classical conditioning. Psychological Science, 12(5), 413-417. https://doi.org/10.1111/1467-9280.00376 
Ozturk, A. B., Nusair, K., Okumus, F., \& Singh, D. (2017). Understanding mobile hotel booking loyalty: an integration of privacy calculus theory and trust-risk framework. Information Systems Frontiers, 19(4), 753-767. https://doi.org/10.1007/s10796-0179736-4

Park, S. (2013). Multidimensional Facets of Perceived Risk in Mobile Travel Booking. Journal of Petrology, 369(1), 1689-1699. https://doi.org/10.1017/CBO9781107415324.004

Ross, M. W., \& Mclaws, M. L. (1992). Subjective norms about condoms are better predictors of use and intention to use than attitudes. Health Education Research, 7(3), 335-339. https://doi.org/10.1093/her/7.3.335

Seth, N., Deshmukh, S. G., \& Vrat, P. (2005). Service quality models: A review. In International Journal of Quality and Reliability Management (Vol. 22, Issue 9). https://doi.org/10.1108/02656710510625211

Sheth, J. N., \& Venkatesan, M. (1968). Risk-Reduction Processes in Repetitive Consumer Behavior. Journal of Marketing Research, 5(3), 307. https://doi.org/10.2307/3150350

Sobh, R., \& Martin, B. A. S. (2011). Feedback information and consumer motivation. European Journal of Marketing, 45(6), 963-986. doi:10.1108/03090561111119976

Szromek, A. R., \& Naramski, M. (2019). A business model in spa tourism enterprises: Case study from Poland. Sustainability (Switzerland), 11(10). https://doi.org/10.3390/su11102880

Unless, R., Act, P., Rose, W., If, T., \& Rose, W. (2016). The Intention-Behavior Gap. Social and Personality Psychology Compass. The University of Sheffield, 10(9), 503-518.

Vryoni, S., Bakirtzoglou, P., \& Ioannou, P. (2017). Customers' Satisfaction and Service Quality of Spa Centers in Greece. Acta Kinesiologica, 11(January), 12-18.

Wellness, G. (2018). Asia-Pacific. November.

Yeo, V. C. S., Goh, S. K., \& Rezaei, S. (2017). Consumer experiences, attitude and behavioral intention toward online food delivery (OFD) services. Journal of Retailing and Consumer Services, 35(July 2016), 150-162. https://doi.org/10.1016/j.jretconser.2016.12.013 